\title{
Personal Hygiene Habits dan Kejadian Flour Albus Patologis pada Santriwati PP AL-Munawwir, Yogyakarta
}

\section{Personal Hygiene Habits and Occurrence of Pathological Fluor Albus on Santriwati of PP Al-Munawwir, Yogyakarta}

\author{
Umi Sa'adatun Nikmah ${ }^{1 *}$, Hesty Widyasih ${ }^{2}$ \\ ${ }^{1}$ Program Studi D-IV Kebidanan, Sekolah Vokasi, Universitas Gadjah Mada, Yogyakarta \\ ${ }^{2}$ Program Studi D-IV Kebidanan, Politeknik Kesehatan Kementerian Kesehatan, Yogyakarta \\ ('umi.saadatun.n@mail.ugm.ac.id)
}

\begin{abstract}
ABSTRAK
Fluor albus adalah cairan yang dikeluarkan dari alat genital wanita dan dibagi menjadi dua, yaitu keputihan fisiologis dan patologis. Keputihan bukan suatu penyakit, tetapi merupakan manifestasi dari hampir semua penyakit kandungan. Penyebab paling sering keputihan adalah infeksi. Personal hygiene habits merupakan salah satu faktor yang memegang peranan penting untuk menghindari infeksi yang dapat menyebabkan keputihan. Penelitian ini bertujuan mengetahui korelasi antara personal hygiene habits dengan kejadian fluor albus patologis. Metode penelitian menggunakan desain cross sectional dengan populasi penelitian santri Pondok Pesantren Al-Munawwir Komplek Q. Pengambilan sampel dilakukan dengan purposive dan random sampling dengan besar sampel 106 santri. Alat pengumpulan data adalah kuesioner personal hygiene habits dan fluor albus. Analisis data menggunakan uji chi-square dan Coefficient Contingency. Hasil penelitian menunjukkan bahwa 52\% santri memiliki personal hygiene habits yang buruk dan sebanyak 75,5 santri mengalami fluor albus patologis. Hasil uji statistik didapatkan $\mathrm{p}=0.000$ dan $\mathrm{C}=0,517$, sehingga terdapat hubungan yang positif dan signifikan antara personal hygiene habits dengan kejadian fluor albus patologis. Semakin buruk personal hygiene habits seseorang, maka keputihan yang dialaminya semakin besar bersifat patologis.
\end{abstract}

Kata kunci : Personal hygiene habits, fluor albus patologis

\section{ABSTRACT}

Fluor albus is fluid secretion from the woman's genitals (vagina) and divided into physiological and pathological. Fluor albus is not a disease but most indication of gynecological problems. The most common cause of pathological fluor albus is infection. Personal hygiene habits are an important factor to avoid an infection which causes fluor albus. This study aims to know the correlation between personal hygiene habits with occurrence of pathological fluor albus, that used cross sectional method with santri as research population in Pondok Pesantren Al-Munawwir Komplek $Q$. The sampling used purposive and random sampling, with sampling size 106 santri, and used personal hygiene habits and fluor albus questionnaires to collect data. Data analysis used chi-square test and Coefficient Contingency test. Results of the study showed that $52 \%$ santri had bad personal hygiene habits and 75,5\% santri were indicated pathological fluor albus. Statistical tests showed $p=0.000$ and $C=0,517$ which means there were positive and significant correlation between personal hygiene habits with occurrence of pathological fuor albus. This is indicating when someone has bad personal hygiene habits, so they are experiencing pathological fluor albus.

Keywords : Personal hygiene habits, pathological fluor albus 


\section{PENDAHULUAN}

World Health Organization (WHO) mendefinisikan kesehatan adalah suatu kondisi sejahtera jasmani, rohani, dan sosial-ekonomi, bukan hanya bebas dari penyakit atau kecacatan. ${ }^{1}$ Widyastuti dalam Riska mendefinisikan kesehatan reproduksi adalah suatu keadaan sejahtera fisik, mental, dan sosial secara utuh, yang tidak semata-mata bebas dari penyakit atau kecacatan dalam semua hal yang berkaitan dengan sistem reproduksi dan fungsi-fungsinya serta prosesnya. ${ }^{2,3}$

WHO menyatakan bahwa masalah kesehatan reproduksi wanita yang buruk telah mencapai $33 \%$ dari jumlah total beban penyakit yang menyerang para wanita di seluruh dunia. ${ }^{4}$ Departemen Kesehatan Republik Indonesia (Depkes RI) dalam Leo, mengemukakan keputihan sebagai gejala yang sangat sering dialami oleh sebagian besar wanita., ${ }^{5,6}$ Keputihan (fluor albus, leuko$r e a$, vaginal discharge) adalah istilah keluarnya cairan dari genitalia seorang wanita yang bukan darah. Secara epidemiologi, fluor albus patologis dapat menyerang wanita mulai dari usia muda, usia reproduksi sehat maupun usia tua dan tidak mengenal tingkat pendidikan, ekonomi dan sosial budaya. ${ }^{7}$ Pada keadaan normal, cairan yang keluar berupa mukus atau lendir yang jernih, tidak berbau mencolok, dan agak lengket. Pada keadaan patologis terjadi perubahan cairan genital dalam jumlah, konsistensi, warna, dan bau. ${ }^{8}$

Masalah kesehatan reproduksi yang ada di Asia sebanyak $76 \%$ yang mengalami keputihan. ${ }^{9}$ Kusmiran dalam Sunarti menyatakan sekitar 90\% remaja putri di Indonesia berpotensi mengalami keputihan karena Indonesia adalah daerah yang beriklim tropis, sehingga jamur, virus dan bakteri mudah tumbuh dan berkembang yang mengakibatkan banyaknya kasus keputihan pada remaja putri Indonesia. Ini menunjukkan remaja putri mempunyai risiko lebih tinggi terhadap infeksi atau keputihan patologis. ${ }^{10,11}$ Berdasarkan data statistik tahun 2009, jumlah remaja putri di DIY, yaitu 2,9 juta jiwa berusia 15-24 tahun $68 \%$ mengalami keputihan patologis. ${ }^{9}$

Keputihan yang terjadi tersebut cenderung disebabkan oleh masih minimnya kesadaran untuk menjaga kesehatan terutama kesehatan organ genitalianya. Selain itu, keputihan sering dikaitkan dengan kadar keasaman daerah sekitar vagina, bisa terjadi akibat $\mathrm{pH}$ vagina tidak seimbang. Sementara kadar keasaman vagina disebabkan oleh dua hal yaitu faktor internal dan faktor eksternal. Faktor eksternal antara lain kurangnya personal hygiene, pakaian dalam yang ketat, dan penggunaan WC umum yang tercemar bakteri Clamydia. ${ }^{12,13}$ Saraswati dalam Paryono menyatakan bahwa penyebab keputihan karena perilaku atau kebiasaan seseorang yang tidak memperhatikan kebersihan organ reproduksinya, yang sering disebut personal hygiene. ${ }^{14,15}$

Personal hygiene habits merupakan salah satu faktor yang memegang peranan penting untuk menghindari infeksi yang dapat menyebabkan keputihan. Hal ini dikarenakan infeksi dapat menyebabkan kanker leher rahim yang merupakan pembunuh nomor satu bagi perempuan. Insiden akibat kanker leher rahim diperkirakan mencapai 100 per 100.000 penduduk per tahun, hal ini bisa berujung pada kematian. ${ }^{6,12}$ Kebersihan merupakan hal yang sangat penting dan harus diperhatikan karena kebersihan akan mempengaruhi kesehatan seseorang. Blum dalam Karina menyatakan bahwa status kesehatan seseorang dapat dipengaruhi oleh lingkungan. ${ }^{16}$ Dalam konteks ini, lingkungan pondok pesantren menjadi menarik untuk diteliti karena pondok pesantren mempunyai kultur tersendiri yang berbeda dengan masyarakat pada umumnya. ${ }^{17}$ Kehidupan di lingkungan pondok pesantren lebih mengutamakan keterbatasan dan kesederhanaan. Hal tersebut menjadikan salah satu faktor yang mempengaruhi kebiasaan berperilaku sehat santri seperti personal hygiene yang kurang baik. Aktivitas padat dimulai dari sebelum subuh hingga sampai kembali tidur sehingga menyebabkan kurang pedulinya santri terhadap kebersihan dirinya terutama genitalia-nya yang mengakibatkan keputihan tersebut.

Pondok Pesantren Al-Munawwir Komplek Q merupakan pondok pesantren khusus putri yang terletak di Yogyakarta, menjadi tempat tinggal para santri yang sangat beragam dari berbagai provinsi di Indonesia. Mayoritas santri di Komplek Q ini berumur 16-24 tahun dan duduk di bangku perkuliahan. Berdasarkan studi pendahuluan penulis $90 \%$ dari 10 sampel santri yang ada di Pondok Pesantren Al-Munawwir Komplek Q mengeluh sering mengeluarkan cairan putih kekuningan dan terasa gatal dari vagina. Kebiasaan santri putri setelah 
buang air tidak dikeringkan dahulu, tidak berganti pakaian dalam ketika merasa lembab, dan berganti pakaian dalam 2 kali dalam sehari, dan kondisi lingkungan yang kurang bersih menjadikan faktor penyebab terjadinya keputihan (flour albus) di lingkungan pondok pesantren tersebut. Tujuan penelitian ini adalah untuk mengetahui korelasi antara personal hygiene habits dengan kejadian flour albus patologis pada santri Pondok Pesantren Al-Munawwir Komplek Q.

\section{BAHAN DAN METODE}

Penelitian ini menggunakan jenis penelitian survei analitik dengan rancangan penelitian studi potong melintang (cross sectional). Penelitian ini dilaksanakan pada bulan Oktober-Desember 2016 di Pondok Pesantren Al-Munawwir Komplek Q, Krapyak Kulon, Sewon, Bantul, D.I. Yogyakarta dengan populasi seluruh santri Komplek Q yang berjumlah 385 santri. Pengambilan sampel dilakukan dengan mixed methods sampling yaitu menggabungkan purposive sampling dan random sampling. Besar sampel dihitung menggunakan rumus survei dari Lemeshow, sehingga diperoleh jumlah sampel 106 santri. Alat pengumpulan data adalah kuesioner personal hygiene habits dan fluor albus Uji validitas dan reliabilitas telah dilakukan sebelum melakukan penelitian. Analisis data menggunakan uji chi-square dan coefficient contingency untuk mengetahui korelasi antara personal hygiene habits dengan kejadian fluor albus patologis dan kekuatannya dengan menggunakan SPSS 23.0.

\section{HASIL}

Karakteristik dasar santri berdasarkan umur, tingkat pendidikan, dan uang saku bulanan. Sebagian besar responden dalam penelitian ini adalah santri kelompok usia remaja akhir (15-19 tahun), yaitu sejumlah 85 santri $(80,2 \%)$ dengan tingkat pendidikan pada perguruan tinggi (D3, D4, dan S1), yaitu sebanyak 71 santri $(67,0 \%)$, dan mayoritas dengan jumlah uang saku bulanan dalam kategori tingkat ekonomi rendah, yaitu uang saku bulanan kurang dari Rp.600.000,00 sebanyak 67 santri $(63,2 \%)$. Peneliti mengategorikan uang saku bulanan berdasarkan mean uang saku seluruh santri dan membagi interval sesuai penilaian objektif.

Sebagian besar subyek penelitian $(52 \%)$
Tabel 1. Distribusi Variabel Penelitian

\begin{tabular}{lcc}
\hline \multicolumn{1}{c}{ Variabel } & $\mathbf{n}=\mathbf{1 0 6}$ & $\mathbf{\%}$ \\
\hline Umur & & \\
$\quad$ Remaja Awal (10-14 tahun) & 21 & 19,8 \\
$\quad$ Remaja Akhir (15-19 tahun) & 85 & 80,2 \\
Tingkat Pendidikan & & \\
$\quad$ SMP/MTs & 20 & 18,9 \\
$\quad$ SMA/MA & 15 & 14,2 \\
$\quad$ D3/D4/S1 & 71 & 67,0 \\
Uang Saku Bulanan & & \\
$\quad$ RRp.600.000,00 & 67 & 63,2 \\
$\quad$ Rp.600.000,00 - Rp.1.000.000,00 & 33 & 31,1 \\
$\quad$ Rp.1.000.000,00 & 6 & 5,7 \\
Personal Hygiene Habits & & \\
$\quad$ Baik & 50 & 48,0 \\
$\quad$ Buruk & 56 & 52,0 \\
Kejadian Fluor Albus Patologis & & \\
$\quad$ Ya & 80 & 75,5 \\
$\quad$ Tidak & 26 & 24,5 \\
\hline
\end{tabular}

Sumber: Data Primer, 2016

memiliki personal hygiene habits yang buruk yaitu sebanyak 56 santri. Sedangkan 50 santri (48\%) memiliki personal hygiene habits yang baik. Berdasarkan Tabel 3, sebagian besar santri di Pondok Pesantren Al-Munawwir Komplek Q Krapyak Yogyakarta mengalami fluor albus patologis yaitu sebanyak 80 santri $(75,5 \%)$ dibandingkan dengan santri yang mengalami fluor albus fisiologis hanya sejumlah 26 santri $(24,5 \%)$. Kejadian keputihan patologis mayoritas terjadi pada remaja awal yaitu remaja yang berusia 10-14 tahun sebanyak $80,1 \%$ dibandingkan dengan remaja akhir. Sedangkan berdasarkan tingkat pendidikan dan uang saku bulanan santri, kejadian fluor albus patologis paling tinggi terjadi pada tingkat SMP/MTs sebanyak $80,0 \%$ dan santri pada tingkat ekonomi tinggi yaitu lebih dari Rp.1.000.000,00, sebanyak 83,3\%.

Tingkat pendidikan, umur, dan uang saku bulanan tidak mempunyai hubungan dengan kejadian fluor albus patologis. Hal ini dapat diketahui dari hasil analisis yang menunjukkan $p>0,05$ yaitu $p=0,514, p=0,867$, dan $p=0,619$ yang berarti bahwa tidak ada hubungan yang signifikan antara tingkat pendidikan dengan kejadian fluor albus patologis, umur dengan kejadian fluor albus patologis, dan uang saku bulanan dengan kejadian fluor albus patologis. Kekuatan korelasi yang dihasilkan dari hasil koefisien kontingensi $\mathrm{C}=0,063$, $\mathrm{C}=0,052$, dan $\mathrm{C}=0,095$. Berdasarkan Tabel 5 dapat 
Tabel 2. Faktor Kejadian Fluor Albus Patologis pada Santri

\begin{tabular}{|c|c|c|c|c|c|c|c|c|c|}
\hline \multirow{3}{*}{ Variabel } & \multicolumn{4}{|c|}{ Fluor Albus } & \multirow{3}{*}{$\Sigma$} & \multirow{3}{*}{$\%$} & \multirow{3}{*}{$\mathbf{X}^{2}$} & \multirow{3}{*}{$\mathbf{p}$} & \multirow{3}{*}{$\mathbf{C}$} \\
\hline & \multicolumn{2}{|c|}{ Fisiologis } & \multicolumn{2}{|c|}{ Patologis } & & & & & \\
\hline & $\mathbf{n}$ & $\%$ & $\mathbf{n}$ & $\%$ & & & & & \\
\hline \multicolumn{10}{|l|}{ Umur } \\
\hline Remaja Awal (10-14 tahun) & 4 & 19,0 & 17 & 80,1 & 21 & 100 & 0,425 & 0,514 & 0,063 \\
\hline Remaja Akhir (15-19 tahun) & 22 & 25,9 & 63 & 74,1 & 85 & 100 & & & \\
\hline \multicolumn{10}{|l|}{ Tingkat Pendidikan } \\
\hline SMP/MTs & 4 & 20,0 & 16 & 80,0 & 20 & 100 & 0,285 & 0,867 & 0,052 \\
\hline SMA/MA & 4 & 26,7 & 11 & 73,3 & 15 & 100 & & & \\
\hline $\mathrm{D} 3 / \mathrm{D} 4 / \mathrm{S} 1$ & 18 & 25,4 & 53 & 74,6 & 71 & 100 & & & \\
\hline \multicolumn{10}{|l|}{ Uang Saku Bulanan } \\
\hline$<\mathrm{Rp} 600.000,00$ & 15 & 22,4 & 52 & 77,6 & 67 & 100 & 0,961 & 0,619 & 0,095 \\
\hline Rp600.000,00 - Rp1.000.000,00 & 10 & 30,3 & 23 & 69,7 & 33 & 100 & & & \\
\hline$>\mathrm{Rp} 1.000 .000,00$ & 1 & 16,7 & 5 & 83,3 & 6 & 100 & & & \\
\hline \multicolumn{10}{|l|}{ Personal Hygiene Habits } \\
\hline Baik & 26 & 52,0 & 24 & 48,0 & 50 & 100 & 38,584 & 0,000 & 0,517 \\
\hline Buruk & 0,0 & 0,0 & 56 & 100,0 & 56 & 100 & & & \\
\hline
\end{tabular}

Sumber: Data Primer, 2016

ditunjukkan bahwa uji chi square didapatkan bahwa nilai $\chi 2=38.584$ berarti $\chi 2$ hitung $>\chi^{2}$ tabel (3.841) dan nilai $p=0,000$ yang berarti $p<0,05$ yaitu terdapat hubungan yang sangat signifikan antara personal hygiene habits dengan kejadian fluor albus patologis dan berdasarkan tabel contingency coefficient nilai $\mathrm{C}$ yang menunjukkan 0,517 yang berarti hubungan kedua variabel tersebut cukup kuat.

\section{PEMBAHASAN}

Berdasarkan hasil penelitian dapat ditunjukkan bahwa masih minimnya personal hygiene habits pada remaja khususnya santri. Banyak faktor yang dapat mempengaruhi personal hygiene seseorang seperti citra tubuh, pengetahuan, budaya, sosial ekonomi, dan kebiasaan santri itu sendiri.

Dalam penelitian ini, peneliti hanya membahas lebih spesifik mengenai kebiasaan santri dalam melakukan personal hygiene yang dihasilkan dari jawaban responden pada kuesioner personal hygiene habits. Faktor lain seperti sosial ekonomi dan pengetahuan, peneliti hanya menjelaskan secara umum dari karakteristik responden yang berupa uang saku dan tingkat pendidikan.

Personal hygiene merupakan perawatan diri sendiri yang dilakukan untuk mempertahankan kesehatan, baik secara fisik maupun psiko- logis. ${ }^{18}$ Personal hygiene habits adalah kebiasaan perawatan diri seseorang untuk mempertahankan kesehatannya, dan dipengaruhi oleh nilai serta keterampilan. ${ }^{19}$ Pemenuhan personal hygiene diperlukan untuk kenyamanan individu, keamanan, dan kesehatan. Kebiasaan melakukan personal hygiene yang baik bertujuan untuk peningkatan kesehatan dimana kulit merupakan garis tubuh pertama dari pertahanan melawan infeksi. Berdasarkan persentase hasil jawaban responden pada kuesioner personal hygiene habits dapat disimpulkan bahwa personal hygiene habits santri masih cenderung buruk. Seseorang dikatakan memiliki kebersihan diri atau personal hygiene yang baik, apabila seseorang tersebut dapat menjaga kebersihan tubuhnya yang meliputi kebersihan kulit, tangan dan kuku, dan kebersihan genitalia. ${ }^{18}$ Dalam penelitian ini personal hygiene habits membahas lebih spesifik mengenai kebiasaan santri dalam membersihkan dirinya terutama organ kewanitaannya. Kebiasaan yang dilakukan santri seperti cara membersihkan organ kewanitaan yang salah, penggunaan handuk bersama, frekuensi penggunaan pembalut dan pantyliner yang belum tepat, frekuensi pemotongan bulu kemaluan yang jarang, penggunaan pakaian dalam yang lembab dan jarang menggantinya, penggunaan antiseptik khusus organ kewanitaan yang kurang tepat, dan peng- 
gunaan air yang kurang higienis dengan keadaan lingkungan yang kotor. Wijayanti dalam Leo menyatakan bahwa kebiasaan-kebiasaan dalam membersihkan diri yang tidak tepat dapat menyebabkan rentannya santri untuk terinfeksi oleh bakteri, virus, maupun jamur karena personal hygiene habits merupakan salah satu pertahanan diri seseorang agar terhindar dari penyakit-penyakit yang mudah menginfeksi.

Membiasakan mencuci tangan terlebih dahulu dan memotong kuku tangan ketika mulai tumbuh panjang sangat penting untuk mencegah berpindahnya bakteri dari tangan ke organ kewanitaan yang bersifat sensitif. Cara membersihkan organ kewanitaan yang benar yaitu dari arah depan ke belakang dimaksudkan agar bakteri dari anus tidak masuk ke dalam vagina. Hal tersebut diimbangi dengan penggunaan air yang bersih yang berasal dari air yang mengalir bukan yang menggenang yang dapat tercemar oleh lingkungan sekitar. Menjaga vagina agar tidak lembab merupakan salah satu cara untuk mencegah terbentuknya lingkungan yang baik untuk berkembang biaknya bakteri maupun jamur. Hal tersebut dapat dilakukan dengan cara mengeringkan vagina dengan handuk pribadi maupun tisu lembut. Penggunaan bahan celana dalam dari katun yang dapat menyerap keringat, tidak ketat, dan sering mengganti celana dalam minimal 2 kali sehari atau segera saat merasa basah. Selain itu, mencukur bulu kemaluan secara rutin dengan gunting pribadi dan steril dapat mencegah vagina agar tidak terlalu lembab dan mencegah penumpukan bakteri, jamur, maupun parasit yang bersarang pada bulu kemaluan.

Penggunaan pembalut yang berbau harum dan mengandung gel tidak diperkenankan karena hal tersebut dapat memicu terjadinya iritasi bahkan kanker pada organ kewanitaan. Pemilihan pembalut yang lembut dan pergantian sesering mungkin setiap 4 jam sekali sangat membantu dalam pencegahan infeksi berupa bakteri. Hal tersebut dikarenakan darah merupakan tempat yang baik untuk bakteri bersarang. Namun, penggunaan pantyliner tidak disarankan saat rutinitas di luar siklus menstruasi karena dapat menyebabkan iritasi pada organ kewanitaan. Wijayanti dalam Leo menyarankan penggunaan antiseptik dalam membersihkan organ kewanitaan tidak diperuntukkan setiap waktu karena dapat mengganggu keseim- bangan PH dan flora normal yang ada pada vagina.

Santri dalam lingkungan pondok pesantren memiliki praktik sosial yang dibentuk secara alamiah dan unik karena santri selama hampir 24 jam berinteraksi dengan lingkungan sosial yang sama dan mempunyai aktivitas sosial yang hampir sama. Selain itu, fasilitas-fasilitas yang tersedia seperti kamar mandi rata-rata untuk 20 santri, kamar tidur yang kurang layak yaitu dengan kapasitas santri 16 orang, dan lingkungan yang padat sangat mempengaruhi bagaimana habits santri dalam menjaga kesehatannya terutama dalam personal hygiene.

Kebersihan lingkungan kamar mandi maupun WC di pondok pesantren kurang diperhatikan, walaupun mungkin terlihat sepele tetapi toilet merupakan tempat yang banyak mengandung bakteri. Frekuensi penggunaan yang sering dengan rasio 28 kali untuk setiap kakusnya dan milik bersama sangat berpotensi membawa bakteri atau jamur sedangkan proses pembersihan kamar mandi hanya dilakukan 3-5 hari sekali. Fransisca menjelaskan bahwa kurang bersihnya kamar mandi atau WC ini secara tidak langsung menularkan bakteri antar satu wanita ke wanita yang lain..$^{20}$ Oleh karena itu, pentingnya menjaga kebersihan kamar mandi atau WC.

Friedman menyatakan bahwa pendapatan keluarga akan mempengaruhi kemampuan keluarga untuk menyediakan fasilitas dan kebutuhankebutuhan yang diperlukan untuk menunjang hidup dan kelangsungan hidup keluarga. ${ }^{21}$ Sumber daya ekonomi seseorang mempengaruhi jenis dan tingkatan praktik personal hygiene. Personal hygiene memerlukan alat dan bahan seperti alat mandi yang semuanya memerlukan uang untuk menyediakannya.

Dalam penelitian ini, peneliti hanya menilai status ekonomi sosial keluarga berdasarkan uang saku bulanan setiap santri. Apabila dibandingkan secara proporsional, hasil penelitian menunjukkan santri dengan tingkat ekonomi tinggi justru mengalami kejadian fluor albus patologis. Hal tersebut menunjukkan tidak ada hubungan antara ekonomi sosial keluarga terhadap personal hygiene habits santri.

Perilaku kesehatan terutama dalam hal personal hygiene habits santri akan dipengaruhi oleh pengetahuan santri itu sendiri. Notoatmodjo dalam Fitri menjelaskan bahwa salah satu faktor yang 
mempengaruhi perilaku seseorang yaitu tingkat pengetahuan. Pengetahuan adalah hasil tahu, dan ini terjadi setelah orang melakukan penginderaan terhadap suatu objek tertentu. Sebagian besar pengetahuan manusia diperoleh melalui melihat dan mendengar. Pengetahuan juga sangat erat dengan pendidikan, sebab pengetahuan didapat baik melalui pendidikan formal mau pun informal. ${ }^{22,23}$ Namun, dalam penelitian ini, tingkat pendidikan santri yang tinggi justru mayoritas mempunyai personal hygiene habits yang buruk. Peneliti menyimpulkan bahwa tingkat pendidikan tidak selalu memiliki pengetahuan yang baik di bidang kesehatan khususnya. Santri akan berperilaku sesuai dengan apa yang diketahui. Santri yang berperilaku tidak sehat menunjukkan bahwa santri itu sendiri tidak mengetahui perilaku tidak sehat tersebut salah dan bisa merusak kesehatan santri, jika tidak ada pihak yang mengingatkan maka perilaku tidak sehat tersebut akan terus dilakukan dalam kehidupan sehari-hari.

Berdasarkan kategori umur, santri pada kategori remaja awal lebih sedikit mengalami keputihan patologis dibandingkan dengan santri pada kategori remaja akhir. Namun, dari total responden 106 santri (100\%) menyatakan mengalami keputihan dalam 6 bulan terakhir. Hal tersebut sesuai teori bahwa keputihan dapat terjadi di segala umur baik remaja kategori awal maupun remaja akhir.

Keputihan adalah nama gejala yang berupa cairan yang dikeluarkan dari alat genital yang tidak berupa darah dan bukan penyakit tetapi merupakan manifestasi dari hampir semua penyakit kandungan. ${ }^{24,25}$ Dalam kondisi normal, kelenjar pada serviks menghasilkan suatu cairan jernih yang keluar, sel-sel vagina yang terlepas dan sekresi dari kelenjar bartolin. ${ }^{26}$ Selain itu, sekret vagina juga disebabkan karena aktivitas flora normal yang hidup pada vagina yang normal. Flora normal meliputi Corynebacterium, Bacteroides, Peptostreptococcus, Gardnerella, Mycoplasma, dan Candida spp. ${ }^{27}$

Dalam penelitian ini, mayoritas santri mengalami keputihan patologis. Kusmiran dalam Sunarti mengatakan bahwa sekitar $90 \%$ remaja putri di Indonesia berpotensi mengalami keputihan karena Indonesia adalah daerah yang beriklim tropis, sehingga jamur, virus dan bakteri mudah tumbuh dan berkembang yang mengakibatkan banyaknya kasus keputihan patologis pada remaja putri di Indonesia. ${ }^{10,11}$ Pada perempuan muda datang dengan keluhan mengeluarkan $d u h$ vagina (keputihan) dengan diagnosis yang paling sering dijumpai adalah hygiene yang buruk. ${ }^{28}$ Hal tersebut juga berlaku dalam penelitian ini, seluruh santri yang memiliki personal hygiene habits yang buruk mengalami fluor albus patologis.

Sedangkan penelitian secara epidemiologi, fluor albus patologis dapat menyerang wanita mulai dari usia muda, usia reproduksi sehat maupun usia tua dan tidak mengenal tingkat pendidikan, ekonomi dan sosial budaya. ${ }^{7}$ Hal tersebut juga sama dengan penelitian ini. Berdasarkan total sampel, mayoritas santri yang berpendidikan tinggi justru yang mengalami keputihan patologis, namun bila secara proporsional santri berpendidikan rendah yang paling tinggi kejadian fluor albus patologisnya. Begitu juga dengan tingkat ekonomi yang rendah maupun tinggi juga mengalami patologis. Selain itu, berdasarkan hasil perhitungan statistik, tiap variabel umur, tingkat pendidikan, dan tingkat ekonomi tidak terdapat hubungan dengan kejadian fluor albus patologis. Hal tersebut menunjukkan bahwa kejadian keputihan patologis dapat beresiko pada setiap wanita.

Berdasarkan penelitian yang telah dilakukan, seluruh santri yang mempunyai personal hygiene habits yang buruk mengalami fluor albus patologis. Hasil ini sesuai dengan teori yang menunjukkan adanya korelasi yang bermakna antara personal hygiene habits seseorang dengan kejadian fluor albus patologis $(\mathrm{p}=0,000)$. Kekuatan korelasi dapat dilihat dari hasil analisis dalam tabel koefisien kontingensi yaitu dengan nilai 0,517 yang berarti cukup kuat sesuai tabel korelasi karena mendekati nilai 1 .

Kebanyakan kasus keputihan pada santri PP Al-Munawwir Komplek Q adalah keputihan patologis. Salah satu faktor penyebabnya adalah banyaknya bakteri-bakteri yang senantiasa berada di dalam vagina yang merupakan flora normal, yang telah berubah sifatnya menjadi bakteri-bakteri patogen disamping adanya mikroorganisme lainnya yang bersifat patogen potensial akibat kurangnya menjaga personal hygiene habits terutama pada organ kewanitaannya seperti kebiasaan membersihkan vagina dari arah belakang ke depan, menggunakan air yang ada di bak atau ember, 
tidak membiasakan mengeringkan vagina setelah $\mathrm{BAK}$ maupun $\mathrm{BAB}$, penggunaan barang pribadi seperti handuk yang bergantian, dan lain sebagainya yang menyebabkan terjadinya keputihan yang bersifat patologis.

Kondisi lingkungan pondok yang kotor merupakan sumber bakteri maupun jamur patogen yang dapat memungkinkan bakteri dan mikroorganisme lainnya yang bersifat patogen potensial masuk ke dalam vagina akibat kontak langsung dengan lingkungan tersebut. Oleh karena itu, pentingnya personal hygiene habits yang harus diimplementasikan oleh setiap santri agar dapat terhindar dari berbagai macam infeksi yang dapat menyebabkan penyakit bagi tubuhnya khususnya pada organ reproduksinya. Selain itu, hal yang harus diperhatikan oleh santri adalah dapat mendeteksi secara dini gejala penyakit yang ganas seperti kanker rahim yang dapat teridentifikasi dalam keputihan sehingga keganasan tersebut dapat dicegah sedini mungkin.

\section{KESIMPULAN DAN SARAN}

Peneliti menyimpulkan bahwa mayoritas santri Pondok Pesantren Al-Munawwir Komplek Q mempunyai personal hygiene habits yang buruk dan mengalami fluor albus yang bersifat patologis. Terdapat korelasi yang signifikan dan cukup kuat antara personal hygiene habits dengan kejadian fluor albus patologis pada santri Pondok Pesantren Al-Munawwir Komplek Q yang berarti semakin buruk personal hygiene habits santri maka semakin besar keputihan yang dialaminya bersifat patologis.

Peneliti menyarankan untuk dapat meningkatkan fasilitas dalam menunjang perbaikan personal hygiene habits santri sangat diperlukan untuk dapat memperbaiki kesehatan pribadinya maupun lingkungannya, sehingga akan terhindar dari penyakit akibat infeksi yang menyerang tubuhnya terutama organ reproduksinya seperti fluor albus yang bersifat patologis. Selain itu, diharapkan untuk peneliti penelitian selanjutnya dapat mendeteksi penyebab dari keputihan yang terjadi pada santri Pondok Pesantren Al-Munawwir Komplek Q secara spesifik seperti pemeriksaan laboratorium sehingga diagnosis didapatkan lebih objektif dan pemberian terapi yang efektif dapat diberikan.

\section{DAFTAR PUSTAKA}

1. WHO. Basic Documents (Including amendments adopted up to 31 December 2014). Forty-eighth ed. Geneva: WHO Press; 2014:1.

2. Widyastuti, Yani, Anita Rahmawati, Yuliasti Eka Purnamaningrum. Kesehatan Reproduksi. Yogyakarta: Fitramaya; 2009:58.

3. Yanti, Riska. Pengaruh Daun Sirih terhadap Penanganan Keputihan pada Remaja Putri di Wilayah Kerja Puskesmas Bandar Khalipah Kecamatan Percut Sei Tuan Kabupaten Deli Serdang Tahun 2014 [Skripsi]. Medan: Universitas Sumatera Utara; 2014.

4. WHO. Mental Health Aspects of Women's Reproductive Health: A Global Review of the Literature. Geneva: WHO Press; 2009:1.

5. Depkes RI. Profil Kesehatan Indonesia. Jakarta : Depkes RI. 2008.

6. Nduru, Leo Marthin. Hubungan Perilaku Mengenai Keputihan dengan Riwayat Kejadian Keputihan pada Ibu-ibu Nelayan di Kelurahan Bagan Deli Kecamatan Medan Belawan [Skripsi]. Medan: Universitas Sumatera Utara; 2016.

7. Kanatasay, Tanisraaj. Karakteristik Pasien Penderita Leukorea di RSUP H. Adam Malik, Medan pada Tahun 2012 [Skripsi]. Medan: USU; 2012.

8. Zubier, Farida. Efikasi Sabun Ekstrak Sirih Merah dalam Mengurangi Gejala Keputihan Fisiologis. Majalah Kedokteran Indonesia. 2010:10.

9. Setiani, Tri Indah, Tri Prabowo, Dyah Pradnya Paramita. Kebersihan Organ Kewanitaan dan Kejadian Keputihan Patologi pada Santriwati di Pondok Pesantren Al Munawwir Yogyakarta. JKNI. 2015;3(1):39-42.

10. Sunarti. Perbedaan Perilaku Remaja Putri dalam Mencegah Keputihan Sebelum dan Sesudah Diterapkan Metode Think Pair Share di Pondok Pesantren As-Salafi Susukan Semarang Semarang: STIKES Ngudi Waluyo Ungaran 2015.

11. Kusmiran, Eny. Kesehatan Reproduksi Remaja dan Wanita. Jakarta: Salemba Medika; 2012. hlm.

12. Kristiana, Dita, Karjiyem, Ery Khusnal. Hubungan Persepsi tentang Kesehatan Reproduksi dengan Personal Hygiene pada Sis- 
wi Sekolah Menengah Pertama. Jurnal Kebidanan dan Keperawatan. 2012;8(1):1-11.

13. Katharini, Kusrini, Yuliawati Prasetyowati. Hubungan Personal Hygiene dengan Kejadian Keputihan pada Siswi SMU Muhammadiyah Metro Tahun 2009. Jurnal Kesehatan "Metro Sai Wawai”. 2009;2(2):45-51.

14. Paryono, Intan Nugraheni. Perilaku Penggunaan Tisu Toilet terhadap Kejadian Keputihan pada Remaja. Jurnal Kebidanan dan Kesehatan Tradisional. 2016;1(1):25.

15. Saraswati, Sylvia. 52 Penyakit Perempuan: Mencegah dan Mengobati 52 Penyakit yang Sering Diderita Perempuan. Yogyakarta: Katahati; 2010.

16. Arvianti, Karina. Hubungan Pengetahuan dan Sikap dengan Gaya Hidup Sehat Mahasiswa S1 [Skripsi]. Jakarta: Universitas Indonesia; 2009.

17. Ikhwanudin, Alim. Perilaku Kesehatan Santri: (Studi Deskriptif Perilaku Pemeliharaan Kesehatan, Pencarian dan Penggunaan Sistem Kesehatan dan Perilaku Kesehatan Lingkungan di Pondok Pesantren Assalafi Al Fithrah, Surabaya). Jurnal Sosial dan Politik. 2013;2(2):3.

18. Ardhiyanti, Yulrina, Risa Pitriani, Ika Putri Damayanti. Panduan Lengkap Keterampilan Dasar Kebidanan I. Yogyakarta: DEEPUBLISH; 2012:105-18.

19. Hoepen, Linell van, Vanessa Verster. Client Services \& Human Relations 2ed. South Africa: Pearson Education; 2008:13-5.

20. Fransisca, Jeanne. Hubungan antara stres psikis menjelang UAN dan SNMPTN dengan Kejadian Fluor Albus pada SIswi SMA Peserta Bimbingan Belajar [Skripsi]. Surakarta: UNS; 2013.

21. Siregar, Syawalina Fithri. Pemenuhan Kebutuhan Personal Hygiene pada Pasien Immobilisasi Post Operasi Fraktur di Ruang Rindu B3 Rumah Sakit Umum Pusat Haji Adam Malik Medan. Medan: Universitas Sumatera Utara; 2010:7.

22. Notoatmodjo, Soekidjo. Metodologi Penelitian Kesehatan. Jakarta: Rineka Cipta; 2002.

23. Ambarwati, Fitri. Hubungan Tingkat Pendidikan dan Tingkat Pengetahuan dengan Kepatuhan Pengguna Pil $\mathrm{Kb}$ di Kecamatan Weru Kabupaten Sukoharjo Tahun 2013 [Skripsi]. Surakarta: UMS; 2014.

24. Manuaba, Ida Bagus Gde. Ilmu Kebidanan, Penyakit Kandungan, dan Keluarga Berencana untuk Pendidikan Bidan. 1 ed. Jakarta: EGC; 1998:385-7,405.

25. Manuaba, Ida Bagus Gde. Penuntun Kepaniteraan Klinik Obstetri dan Ginekologi. 2 ed. Jakarta: EGC; 2004:240,83,320.

26. Farrer, Hellen. Maternity Care. 2 ed. Jakarta: EGC; 2001:20,252.

27. Hay, Phillip E. Bacterial Vaginosis as a Mixed Infection. Washington DC: ASM Press; 2002:125-36.

28. Mayasari, Intan Cristi, Siti Khuzaiyah, Rini Krisiyanti. Karakteristik Wanita dengan Fluor Albus. Jurnal Ilmu Kesehatan (JIK); 2015; 3:3. 